\title{
Desain Sistem Pengukuran Parameter dan Keamanan Penerangan Jalan Umum Tenaga Surya Berbasis Internet of Thing (IoT)
}

\author{
Muhaimin Toh-Arlim ${ }^{1}$, Alfian Ma'arif ${ }^{2 *}$, Aninditya Anggari Nuryono ${ }^{3}$
}

[Submission: 27-07-2021, Accepted:18-12-2021]

\begin{abstract}
This study discusses the monitoring system for voltage, current, power and safety of solar street lighting (PJUTS) using a smartphone and the Internet of Things (IoT) based Blynk application. Public street lights that are damaged and prone to theft require monitoring and security systems. As a measurement of voltage, current and power, the INA219 current sensor is used. The sensor value will be read by the NodeMCU microcontroller and sent with IoT to be displayed in the Blynk application on the cellphone so that the processed information can be seen. PIR sensors and ultrasonic sensors are used to identify and detect objects around PJUTS lights so that they can function as safety for street lights. In the estimation of battery charging, the solar cell gets the highest light at the estimated 12:00-13:00 with a value of 99800 and produces 6.97 watts of power, with a voltage of 11.8 volts and a current of 0.6 amperes. The farthest distance of the PIR sensor that can identify the movement of an object approaching the system is 5 meters with the closest distance of 1 meter. The size of the data sent to Blynk within 24 hours is 119.16MB.
\end{abstract}

Intisari-Penelitian ini membahas tentang sistem pemantauan (monitoring) tegangan, arus, daya dan keamanan lampu penerangan jalan umum tenaga surya (PJUTS) menggunakan smartphone dan aplikasi Blynk berbasis internet of Things (IoT). Lampu jalan umum yang rentang rusak dan rentan pencurian memerlukan sistem pemantauan dan keamanan. Sebagai pengukuran tegangan, arus dan daya digunakan sensor arus INA219. Nilai sensor akan dibaca oleh mikrokontroler NodeMCU dan dikirim dengan IoT untuk ditampilkan di aplikasi Blynk di ponsel sehingga informasi yang diproses dapat dilihat. Sensor PIR dan sensor ultrasonik digunakan untuk mengidentifikasi dan mendeteksi objek di sekitar lampu PJUTS sehingga dapat difungsikan sebagai pengaman untuk lampu jalan. Pada estimasi pengisian baterai, solar sel mendapat cahaya paling tinggi pada estimasi pukul 12:00-13:00 dengan nilai 99800 dan menghasilkan daya 6,97 watt, dengan tegangan 11,8 volt dan arus 0,6 ampere. Jarak terjauh sensor PIR yang dapat mengidentifikasi pergerakan suatu objek yang mendekati sistem adalah 5 meter dengan jarak terdekat 1 meter. Ukuran data yang dikirim ke Blynk dalam waktu 24 jam sebesar 119,16MB.

Kata Kunci- Internet of Thing (IoT), NodeMCU, Monitoring, Lampu Penerangan Jalan Umum, Security, Panel Surya

\footnotetext{
${ }^{1}$ Universitas Ahmad Dahlan, Yogyakarta, Indonesia

${ }^{2}$ Universitas Ahmad Dahlan, Yogyakarta, Indonesia e-mail: alfianmaarif@ee.uad.ac.id

${ }^{3}$ Universitas Mulia, Balikpapan, Indonesia
}

\section{Pendahuluan}

Penerapan tenaga matahari sebagai sumber energi yang dapat digunakan untuk penerangan jalan banyak diimplementasikan di perkotaan dan pedesaan [1][2][3][4][5]. Lampu jalan tenaga surya otomatis dapat menyala di sore hari dan mati di pagi hari dengan perawatan yang mudah dan efisien [6]. Pemanfaatan tenaga surya juga dapat mengurangi anggaran biaya maupun anggaran negara [7][8]. Namun, ada beberapa batasan penggunaan panel surya, seperti daya tahan baterai yang terbatas dan umur baterai yang pendek [9]. Beberapa penyebab masalah tersebut adalah penggunaan baterai secara terus menerus dan tidak memperhatikan kapasitas baterainya serta penggunaan baterai dengan arus searah yang terlalu banyak [10]. Di samping itu, telah terjadi pencurian perangkat lampu penerangan jalan umum seperti di kabupaten kulonprogo, Daerah Istimewa Yogyakarta yang disebabkan karena diambil oleh pencuri. Perangkat yang hilang berupa aki kering dan panel tenaga surya yang terdapat di bagian atas [11].

Untuk mengatasi masalah tersebut, sistem monitoring dan manajemen tegangan, daya dan keamanan perlengkapan penerangan jalan umum berbasis solar sel perlu untuk diusulkan. Saat ini perkembangan teknologi Internet of Things (IoT) berkembang pesat di berbagai sistem [12][13][14]. Salah satunya mengintegrasikan berbagai sistem pengindraan tegangan dan arus yang terhubung ke Internet untuk pemantauan data online melalui aplikasi [15][16]. Internet of Things (IoT) adalah konsep jaringan yang memediasi objek untuk komunikasi sehingga tidak memerlukan interaksi orang ke orang atau orang ke komputer [17][18]. Internet of Things dapat berkomunikasi satu sama lain melalui Internet [19][20].

Pada penelitian sebelumnya, IoT sudah diterapkan dalam pengukuran $\mathrm{kWh}$ meter yang didistribusikan oleh PLN secara langsung [21][22][23][24][25]. Metode tersebut memudahkan pengguna untuk melacak konsumsi daya. Sistem IoT sudah dapat digunakan untuk mengukur suatu parameter berdasarkan pada penelitian sebelumnya [26][27]. Pada penelitian lain, sensor INA219 digunakan untuk mengukur tegangan dan arus yang mengalir melalui beban [28] namun hanya sebatas pada komunikasi lokal. Penelitian lain mengusulkan metode yang hampir mirip [29][30] namun menggunakan fitur SMS. Sementara pada penelitian ini mengusulkan tentang komunikasi IOT dengan kelebihan dapat melakukan monitoring dimanapun dan kapanpun melalui internet.

Berdasarkan latar belakang, penelitian ini akan merekomendasikan sistem IoT untuk memantau parameter tegangan dan arus beserta sistem keamanan perangkat. Sensor INA219 digunakan untuk mengukur tegangan dan arus yang mengalir melalui beban. Informasi data arus sensor INA219 akan diproses oleh mikrokontroler yang kemudian akan dikirim 
ke sistem cloud blynk [31] melalui kode token tertentu, kemudian informasi tersebut dapat diunduh melalui ponsel dan ditampilkan di aplikasi blynk di ponsel. Data monitoring tegangan, arus dan daya akan diperbaharui setiap waktu dengan sebelumnya dikalibrasi mendekati nilai aslinya. Dalam pembaharuan tersebut diperlukan data internet yang didapatkan dari wifi yang dipancarkan smartphone yang telah terkoneksi. Selain itu juga terdapat sensor PIR dan ultrasonik yang berfungsi untuk mendeteksi objek di sekitar lampu PJU.

Terdapat beberapa bagian pada artikel ini yaitu bagian pendahuluan yang membahas tentang latar belakang penelitian. Bagian kedua adalah metode penelitian yang membahas tentang diagram alir penelitian, desain sistem, diagram blok sistem, diagram pengkabelan sistem, desain tiga dimensi dan diagram alir sistem. Bagian selanjutnya adalah hasil dan pembahasan yang membahas tentang analisis hasil pengujian sistem. Bagian terakhir adalah kesimpulan.

\section{Metode}

Gambar 1 menunjukkan diagram skema sistem pemantauan. Pada penelitian ini diharapkan dapat terciptanya monitoring tegangan, arus, dan daya lampu jalan yang dapat mengirim peringatan secara realtime dan dapat diakses melalui internet. Pada penelitian ini dilakukan prosedur untuk mengidentifikasi masalah penerangan umum berbasis solar sel. Faktor permasalahan adalah pengukuran parameter secara daring dan keamanan perlengkapan penerangan umum. Dokumentasi pendukung kemudian direvisi untuk merancang lebih lanjut perangkat keras yang sesuai. Setelah desain perangkat keras selesai, perangkat lunak dirancang untuk membaca data dari tiga sensor. Tes lebih lanjut akan dilakukan. Jika dapat menampilkan data pengukuran / deteksi pada ponsel cerdas, itu akan dapat berfungsi normal. Namun, jika tidak dapat dibaca dan dikirim secara real time, maka akan dilakukan pengujian hardware dan software.

\section{A. Desain Sistem}

Saat merancang sistem ini, desain sistem terbagi dalam dua tahapan desain yaitu desain perangkat keras dan desain perangkat lunak. Langkah pertama dalam merancang sistem ini adalah membuat blok diagram perangkat keras kemudian membangun sistem pengukuran dan rangkaian sensor. Langkah kedua adalah membuat perangkat lunak/kontrol yang digunakan untuk mengoperasikan sistem pemantauan.

\section{B. Perancangan Hardware}

Perancangan perangkat keras sistem monitoring menggunakan NodeMCU [32] yang berperan sebagai pengontrol sensor dan memproses data yang dibaca dari masing-masing sensor. Gambar 2 menunjukkan diagram blok dari desain sistem meliputi perangkat berbasis Internet of Things (IoT), keamanan lampu jalan surya dan desain sistem pengukuran parameter. Mikrokontroller menggunakan ESP8266 NodeMCU [33] sebagai pengolah data membaca data sensor. Data Ini kemudian dikirim ke pengguna nirkabel. Sensor INA219 bertindak sebagai pembaca nilai arus, tegangan dan daya beban [34][35]. Dari segi keamanan, sensor PIR [36][37] dan sensor ultrasonik digunakan sebagai pendeteksi gerakan atau objek [38].

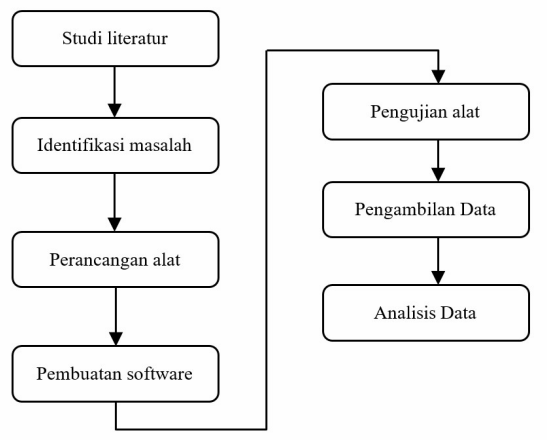

Gambar 1. Diagram Alir Penelitian

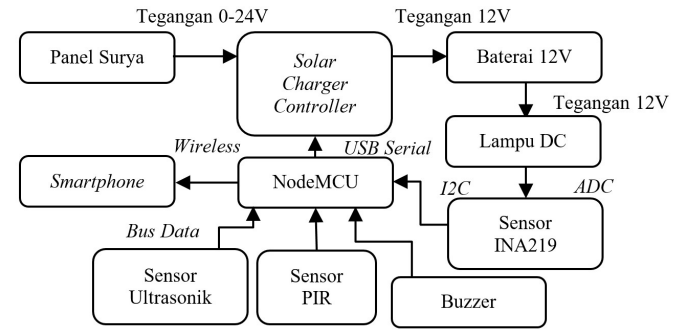

Gambar 2. Diagram Blok Perancangan Sistem

Cara kerja dari alat yang ditunjukkan yaitu dimulai saat solar panel telah selesai melakukan pengisian daya baterai dan solar charge controller mengalirkan tenaga ke beban. Sensor INA219 kemudian akan mengukur arus dan tegangan yang masuk. NodeMCU akan menangani perhitungan tanda yang dikirim dari sensor INA219 untuk mengubahnya menjadi flag terkomputerisasi dan mengirimkannya ke web menggunakan modul wifi di NodeMCU. Informasi saat ini akan diunduh oleh aplikasi Blynk [39][40] di ponsel, dan aplikasi akan menampilkan informasi tegangan dan arus secara progresif.

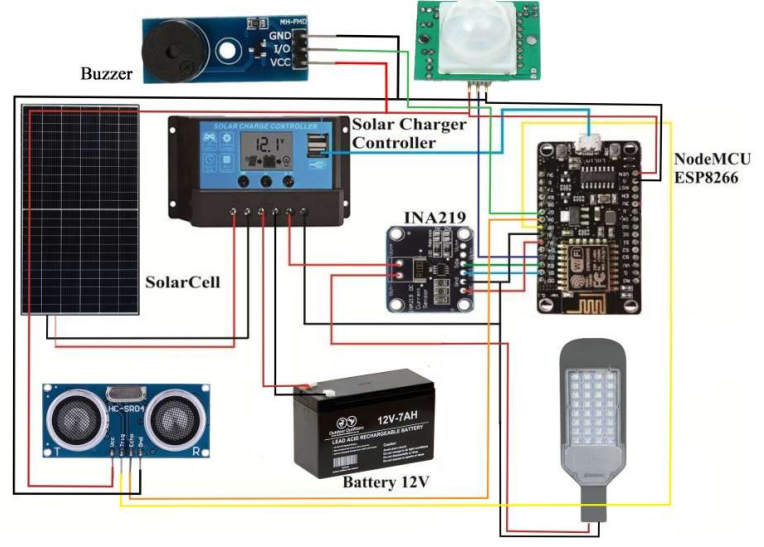

Gambar 3. Diagram Perancangan Sistem

Pada diagram sistem Gambar 3 menggunakan komponen utama berupa panel surya sebagai sumberi tenaga listrik yang mengonversikan cahaya matahari menjadi tenaga listrik. Tenaga yang dihasilkan dari solar panel dialirkan ke power box yang di dalamnya terdapat solar charge controller (SCC) [41] untuk mengontrol pengisian baterai dari panel surya, baterai $12 \mathrm{~V}$ untuk menyimpan tenaga listrik dari panel surya, dan sistem kontrol IoT yang berupa NodeMCU dan relai sebagai monitoring tegangan dan arus yang melalui dari baterai ke 
Majalah Ilmiah Teknologi Elektro, Vol. 20, No.2, Juli-Desember 2021

DOI: https://doi.org/10.24843/MITE.2021.v20i02.P18

perangkat. Sensor INA219 sebagai sensor pembaca tegangan dan arus yang sudah diproses ke NodeMCU untuk dikonversi ke data digital dan dapat ditampilkan pada ponsel. Pengkabelan rangkaian pada NodeMCU dapat dilihat seperti pada Tabel I dan Gambar 4. Sensor INA219 terhubung dengan PIN D1 dan D2 dengan komunikasi I2C. Sensor PIR terhubung dengan PIN D3. Sensor ultrasonik HC SR04 terhubung dengan PIN D5 dan D6.

TABEL II

ALAMAT PIN INPUT OUTPUT

\begin{tabular}{|c|c|}
\hline Pin NodeMCU & Sensor / Aktuator \\
\hline D1, D2 & Sensor INA219 \\
\hline D3 & Sensor PIR \\
\hline D5, D6 & Sensor HC-SR04 \\
\hline D7 & Buzzer \\
\hline
\end{tabular}

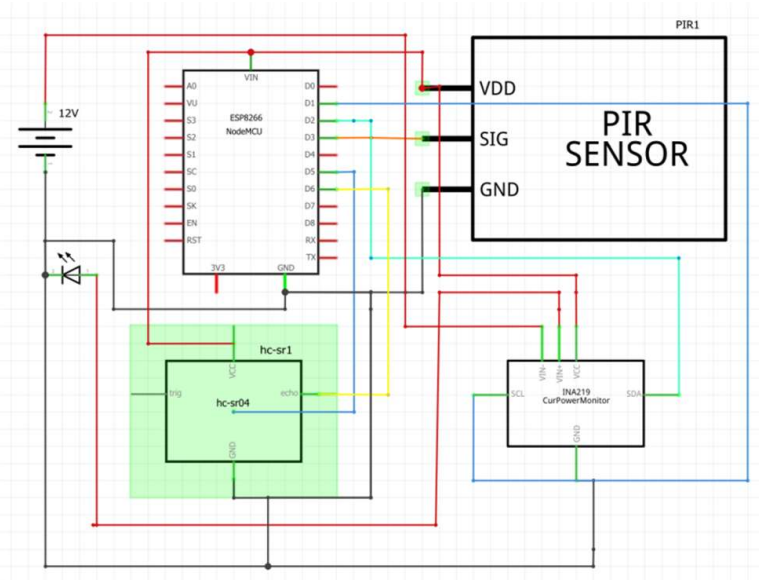

Gambar 4. Diagram Rangkaian Pengkabelan Sistem

\section{Desain $3 D$}

Dari rangkaian keseluruhan sistem yang telah dibuat dapat dilihat rancangan desain luaran alat pada Gambar 5. Lampu PJUTS dilengkapi dengan Panel Surya, Box Kontroler, lampu dan tiang. Pada Box Controller akan tersimpan baterai, Solar charger controller dan komponen lain seperti NodeMCU dan sensor-sensor.

\section{Perancangan Perangkat Lunak (Software)}

Dalam penelitian ini menggunakan software Arduino IDE untuk memprogram Node MCU dengan bahasa C. Sebelum memprogram dengan software Arduino IDE, terlebih dahulu harus membuat diagram alir. Dalam hal ini, ketika sistem menghubungkan tegangan input ke baterai, mikrokontroler memulai proses inisialisasi input dan output dan variabel yang diperlukan. Data yang dimasukkan di NodeMCU ESP8266 diproses.

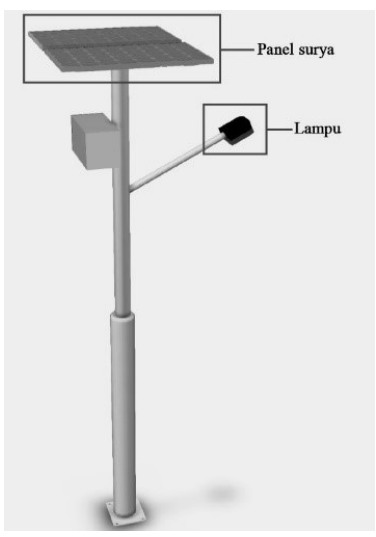

Gambar 5. Desain 3D

Gambar 6 adalah diagram alir sistem lampu PJUTS berbasis IoT. Sistem dimulai dengan mengisi baterai menggunakan panel surya dengan solar charger controller (SCC). Baterai yang terhubung ke SCC cukup untuk mengaktifkan NodeMCU dan kemudiannya menunggu koneksi internet untuk dikirim melalui smartphone. Saat terhubung ke internet, NodeMCU akan langsung memproses data parameter pengukuran tegangan dan arus dari sensor INA219 dan mengirimkannya ke server Blynk berdasarkan alamat token. Aplikasi smartphone Blynk menampilkan data parameter yang dikirimkan secara numerik. Aplikasi Blynk juga terdapat pengaturan sensor HCSRF-04 yang menentukan jarak. Lampu menyala atau mati untuk jangka waktu yang telah ditentukan.

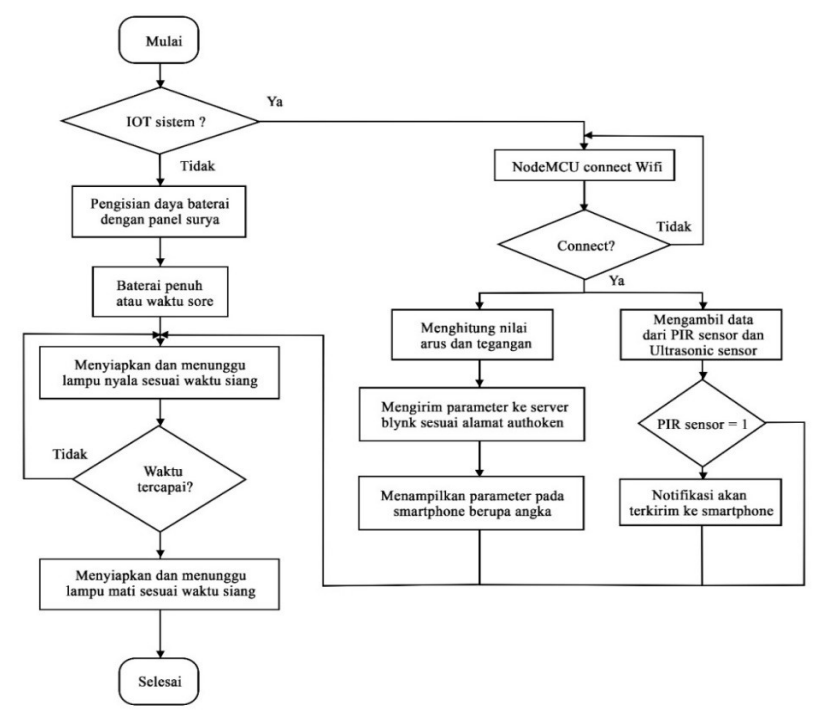

Gambar 6. Diagram Alir Proses Pembacaan dan Pengiriman data

\section{HASIL DAN PEMBAHASAN}

Pengujian data dilakukan dengan mencocokkan keluaran sensor sesuai dengan alat yang sudah terkalibrasi. Kedua, mengambil data arus, tegangan, dan daya yang dibaca sensor. Hasil ini dibandingkan dengan pembacaan pada multimeter. Selain itu, pengujian data dilakukan pada lampu bermula dari jam 18.00 hingga 04.00. Hasil pengujian sensor arus INA219 
dan pengukuran nilai arus dengan menggunakan multimeter ditunjukkan pada Tabel 1.

Untuk self-test pengiriman nirkabel, hal ini dilakukan dengan mengambil data siang hari dari pengisian baterai melalui panel surya dan mengukur penggunaan daya pada waktu malam hari. Pembacaan data yang telah terkirim melalui NodeMCUE SP8266 menggunakan smartphone. Pada pengiriman data ke ponsel pengguna, diperlu menghubungkan NodeMCUE SP8266 melalui Wi-Fi terlebih dahulu. Ketika NodeMCU ESP8266 terhubung, transfer data akan berjalan secara nirkabel. Data berhasil terkirim dengan memasukkan username dan password yang sesuai untuk masuk ke dalam daftar program. Mengirim data pembaruan yang sedang berlangsung mungkin membutuhkan waktu lama untuk menentukan apakah data parameter sensor INA219 valid. Kemudian lakukan uji coba dengan multimeter dan uji coba pada lampu yang terhubung. Selisih dan persentase dapat dihitung dengan menggunakan persamaan berikut

Selisih = Nilai Referensi - Nilai Sensor,

\section{Persentase kesalahan}

$$
=\frac{\mid \text { Selisih } \mid}{\mid \text { Nilai Referensi } \mid} \times 100 \text {. }
$$

TABEL II

PENGUJIAN SENSOR DENGAN ALAT UKUR

\begin{tabular}{|c|c|c|c|c|c|c|c|c|c|c|}
\hline \multirow{2}{*}{ Variasi Waktu } & \multirow{2}{*}{ Lampu } & \multicolumn{2}{|c|}{ Pengukuran menggunakan sensor } & \multicolumn{2}{|c|}{ Pengukuran menggunakan multimeter } & \multicolumn{4}{|c|}{ Selisih (\%) } \\
\cline { 4 - 14 } & & Voltase (V) & Arus (A) & Daya (Watt) & Voltase (V) & Arus (A) & Daya (Watt) & Voltase (V) & Arus (A) & Daya (Watt) \\
\hline $18.00-19.00$ & On & 12,76 & 0,376 & 4,798 & 12,74 & 0,372 & 4,739 & 0,02 & 0,004 & 0,058 \\
\hline $19.00-20.00$ & On & 12,63 & 0,368 & 4,648 & 12,62 & 0,362 & 4,568 & 0,01 & 0,006 & 0,079 \\
\hline $20.00-21.00$ & On & 12,61 & 0,362 & 4,565 & 12,57 & 0,359 & 4,513 & 0,04 & 0,003 & 0,052 \\
\hline $21.00-22.00$ & On & 12,56 & 0,355 & 4,459 & 12,54 & 0,347 & 4,351 & 0,02 & 0,008 & 0,107 \\
\hline $22.00-23.00$ & On & 12,47 & 0,348 & 4,340 & 12,44 & 0,346 & 4,304 & 0,03 & 0,002 & 0,035 \\
\hline $23.00-00.00$ & On & 12,42 & 0,341 & 4,235 & 12,37 & 0,337 & 4,169 & 0,05 & 0,004 & 0,067 \\
\hline $00.00-01.00$ & On & 12,35 & 0,334 & 4,125 & 12,29 & 0,329 & 4,043 & 0,06 & 0,005 & 0,081 \\
\hline $01.00-02.00$ & On & 12,09 & 0,253 & 3,059 & 12,07 & 0,250 & 3,018 & 0,02 & 0,003 & 0,041 \\
\hline $02.00-03.00$ & On & 11,89 & 0,223 & 2,651 & 11,82 & 0,217 & 2,565 & 0,07 & 0,006 & 0,087 \\
\hline $03.00-04.00$ & On & 11,82 & 0,218 & 2,577 & 11,74 & 0,215 & 2,524 & 0,08 & 0,003 & 0,053 \\
\hline
\end{tabular}

\section{1) Pengambilan Data pada PJUTS}

Data pengukuran diperoleh berupa data arus dan tegangan dari pengisian baterai dan pengujian lampu yang dilakukan selama beberapa hari. Dalam satu hari, pengukuran pengisian baterai melalui panel surya dilakukan pada jam 07.00 hingga 17.00 dan untuk pemantauan lampu pada jam 18.00 hingga 04.00. Hasil pengambilan data dapat dilihat pada Tabel III dan Tabel IV.

Hasil data dari perhitungan tegangan, arus dan daya diambil selama dua hari yang berbeda cuaca yaitu pada hari pertama adalah pengambilan data pada cuaca panas dan pada hari kedua adalah pengambilan data pada cuaca mendung. Dengan pengambilan intensitas matahari (lux) yang dapat membedakan cuaca dan hubungan luxmeter pada sinar matahari yang dapat dikonversi oleh sel surya menjadi tenaga listrik [42].
Berdasarkan Tabel II perhitungan sensor INA219 tersebut pada variasi waktu 18.00-19.00 terdapat selisih voltase (V) sebesar $0,16 \%$, arus (I) $1,08 \%$, daya (P) $1,23 \%$, pada variasi waktu $19.00-20.00$ terdapat selisih voltase $(\mathrm{V})$ sebesar $0.08 \%$, arus (I) $1,66 \%$, daya (P) $1,74 \%$, pada variasi waktu $20.00-21.00$ terdapat selisih voltase (V) sebesar $0,32 \%$, arus (I) $0,84 \%$, daya (P) $1,16 \%$, pada variasi waktu $21.00-22.00$ terdapat selisih voltase (V) sebesar $0,16 \%$, arus (I) $2,31 \%$, daya (P) $2,47 \%$, pada variasi waktu $22.00-23.00$ terdapat selisih voltase (V) sebesar $0,24 \%$, arus (I) $0,58 \%$, daya (P) $0,82 \%$, pada variasi waktu 23.00-00.00 terdapat selisih voltase (V) sebesar 0,40\%, arus (I) $1,19 \%$, daya (P) $1,60 \%$, pada variasi waktu $00.00-01.00$ terdapat selisih voltase (V) sebesar $0,49 \%$, arus (I) $1,52 \%$, daya (P) 2,02\%, pada variasi waktu 01.00-02.00 terdapat selisih voltase (V) sebesar $0,17 \%$, arus (I) $1,20 \%$, daya (P) $1,37 \%$, pada variasi waktu 02.00-03.00 terdapat selisih voltase (V) sebesar $0,59 \%$, arus (I) $2,76 \%$, daya (P) 3,37\%, pada variasi waktu $03.00-04.00$ terdapat selisih voltase $(\mathrm{V})$ sebesar $0,68 \%$, arus (I) $1,40 \%$, daya (P) $2,09 \%$. Pada data perhitungan sensor tersebut terlihat berbedaan atau selisih pada hasilnya yang tidak terlalu jauh selisihnya.
Grafik pada Gambar 7 menunjukkan data grafik tegangan dua kondisi cuaca yang berbeda, yaitu keadaan panas dan keadaan mendung. Data keadaan panas merupakan hasil pengukuran hari pertama dan data keadaan cuaca mendung merupakan hasil pengukuran hari kedua.

Pada grafik, dapat melihat perbedaan antara keduanya dalam kondisi panas dan berawan atau mendung. Grafik menunjukkan perbedaan tegangan ketika baterai isi ulang mencapai muatan maksimum 14,2 V pada suhu tinggi. Di sisi lain, meskipun mendung, Anda dapat tetap mengisi daya baterai dengan lampu menyala.

Pada grafik yang telah ditampilkan pada Gambar 8 merupakan data grafik arus. Data kondisi panas, bentuk grafik terlihat jelas pada rantang waktu 15:00-19:00 ketika arus menurun untuk membatasi pengisian baterai setelah baterai dalam keadaan penuh. Kemudian akan mula meningkat 
Majalah Ilmiah Teknologi Elektro, Vol. 20, No.2, Juli-Desember 2021

DOI: https://doi.org/10.24843/MITE.2021.v20i02.P18

Kembali Ketika pemakaian beban. Pada kondisi cuaca mendung pula pengisian arus berlaku secara berterusan sehingga pemakaian beban.

Menurut hasil pengujian perangkat yang dilakukan, jika pengaliran muatan daya pada baterai dengan panel surya dari jam 7 pagi, rata-rata pengisian baterai akan selesai pada jam 3 sore. Dibutuhkan sekitar 7 hingga 8 jam untuk mengisi baterai dalam keadaan hangat atau cuaca panas. Menurut data pada tabel tersebut, hari yang kedua, dalam 1 jam tegangan baterai hanya meningkat sebesar 0,2 hingga 0,3 volt. Bahkan pada jam 5.00 sore voltase maksimum yang tercatat hanya $13 \mathrm{~V}$.

Hal ini berbeda dengan pengujian tegangan dan arus yang menyertakan sensor INA219 sebagai sensor yang membaca arus dan tegangan yang mengalir melalui beban. Sensor terhubung ke node MCU sebagai pengolah data untuk ditampilkan nanti di aplikasi Blynk. Sumber tegangan rangkaian perangkat keras yang mengukur tegangan dan arus adalah dari port USB Solar Charge Controller yang terhubung dengan NodeMCU sebagai mikrokontroler, yang memiliki output $5 \mathrm{~V}$. Dengan ini sensor-sensor yang terhubung dengan mikrokontroler dapat berfungsi dengan terhubung pin VCC dan GND.

NodeMCU mengunduh nilai parameter terukur yang diproses di server platform Blynk. Untuk mengunduh nilai ini,
337

diperlukan token autentikasi yang disinkronkan dengan Blynk. Otentikasi dicapai ketika mulai menggunakan Blynk. Setelah melakukan sinkronisasi dengan Blynk, smartphone mengunduh data yang ada dan menampilkannya sesuai perintah pada interface blynk. Gambar 9 menunjukkan hasil antarmuka aplikasi Blynk. Ini termasuk pemantauan tegangan dan arus serta daya dalam bentuk tampilan nilai dan bacaan.

Selama penggunaan, aplikasi Blynk membutuhkan koneksi internet yang diperoleh dari tethering Wi-Fi ponsel pengguna. Secara berkala, Blynk memperbarui data yang diunduh dan menggunakan kuota data Internet. Ini adalah data internet yang dibutuhkan aplikasi Blynk 24 jam dalam sehari, tanpa gangguan.

Pengukuran dimulai pada jam 5 pagi dan total data pengukuran 24 jam adalah 119,16 MB. Pada pukul 6 pagi, data yang ditulis adalah 5,24MB dan penggunaan data maksimum adalah sekitar jam 17:42 hingga 18:42, atau 7,84MB. Artinya, aplikasi Blynk hanya menggunakan sekitar 5,00-8,00MB data internet per jam, atau $\pm 0,1 \mathrm{MB}$ per detik. Oleh karena itu, kami dapat menyimpulkan bahwa penggunaan data Internet oleh aplikasi Blynk memungkinkan data untuk diunduh dalam jumlah kecil.

TABEL III

DATA PENGUKURAN PANEL SURYA

\begin{tabular}{|c|c|c|c|c|c|c|c|c|c|c|c|c|}
\hline \multicolumn{10}{|c|}{ Variabel } & \multicolumn{10}{|c|}{ Variasi Waktu } & Rata-Rata \\
\hline \multicolumn{2}{|c|}{} & $\begin{array}{c}7.00- \\
8.00\end{array}$ & $\begin{array}{c}8.00- \\
9.00\end{array}$ & $\begin{array}{c}9.00- \\
10.00\end{array}$ & $\begin{array}{c}10.00- \\
11.00\end{array}$ & $\begin{array}{c}11.00- \\
12.00\end{array}$ & $\begin{array}{c}12.00- \\
13.00\end{array}$ & $\begin{array}{c}13.00- \\
14.00\end{array}$ & $\begin{array}{c}14.00- \\
15.00\end{array}$ & $\begin{array}{c}15.00- \\
16.00\end{array}$ & $\begin{array}{c}16.00- \\
17.00\end{array}$ & \\
\hline & $\mathrm{V}$ & 11,10 & 12,30 & 12,50 & 12,70 & 13,10 & 13,40 & 13,41 & 14,10 & 14,20 & 14,12 & 13,09 \\
\hline 1 & $\mathrm{~A}$ & 0,320 & 0,350 & 0,370 & 0,480 & 0,510 & 0,520 & 0,510 & 0,420 & 0,001 & 0,001 & 0,35 \\
\hline & $\mathrm{W}$ & 3,55 & 4,31 & 4,63 & 6,10 & 6,68 & 6,97 & 6,84 & 5,92 & 0,01 & 0,01 & 4,50 \\
\hline & $\mathrm{Lx}$ & 51000 & 62200 & 76300 & 95400 & 98400 & 99800 & 93800 & 63400 & 54200 & 23400 & 71790 \\
\hline & $\mathrm{V}$ & 12,21 & 12,24 & 12,33 & 12,45 & 12,54 & 12,82 & 13,00 & 13,11 & 13,18 & 13,21 & 12,71 \\
\hline 2 & $\mathrm{~A}$ & 0,100 & 0,150 & 0,210 & 0,280 & 0,220 & 0,270 & 0,260 & 0,290 & 0,210 & 0,220 & 0,22 \\
\hline & $\mathrm{W}$ & 1,22 & 1,84 & 2,59 & 3,49 & 2,76 & 3,46 & 3,38 & 3,80 & 2,77 & 2,91 & 2,82 \\
\hline & $\mathrm{Lx}$ & 25300 & 26300 & 27600 & 21300 & 20600 & 26100 & 27400 & 23700 & 21100 & 20100 & 23950 \\
\hline
\end{tabular}

TABEL IV

DATA MONITORING LAMPU

\begin{tabular}{|c|c|c|c|c|c|c|c|c|c|c|c|c|}
\hline \multicolumn{10}{|c|}{ Variabel } & \multicolumn{10}{|c|}{ Variasi Waktu } & Rata-Rata \\
\hline \multicolumn{2}{|c|}{} & $\begin{array}{c}18.00- \\
19.00\end{array}$ & $\begin{array}{c}19.00- \\
20.00\end{array}$ & $\begin{array}{c}20.00- \\
21.00\end{array}$ & $\begin{array}{c}21.00- \\
22.00\end{array}$ & $\begin{array}{c}22.00- \\
23.00\end{array}$ & $\begin{array}{c}23.00- \\
0.00\end{array}$ & $\begin{array}{c}0.00- \\
1.00\end{array}$ & $\begin{array}{c}1.00- \\
2.00\end{array}$ & $\begin{array}{c}2.00- \\
3.00\end{array}$ & $\begin{array}{c}3.00- \\
4.00\end{array}$ & \\
\hline & V & 12,76 & 12,63 & 12,61 & 12,56 & 12,47 & 12,42 & 12,35 & 12,09 & 11,89 & 11,82 & 12,36 \\
\hline 1 & A & 0,376 & 0,368 & 0,362 & 0,355 & 0,348 & 0,341 & 0,334 & 0,253 & 0,223 & 0,218 & 0,318 \\
\hline & W & 4,798 & 4,648 & 4,565 & 4,459 & 4,340 & 4,235 & 4,125 & 3,059 & 2,651 & 2,577 & 3,946 \\
\hline & V & 12,61 & 12,45 & 12,41 & 12,34 & 12,11 & 11,83 & 11,76 & 11,71 & 11,54 & 10,37 & 11,91 \\
\hline 2 & A & 0,352 & 0,341 & 0,340 & 0,332 & 0,250 & 0,219 & 0,217 & 0,212 & 0,191 & 0,088 & 0,254 \\
\hline & W & 4,439 & 4,245 & 4,219 & 4,097 & 3,028 & 2,591 & 2,552 & 2,483 & 2,204 & 0,913 & 3,077 \\
\hline
\end{tabular}

Muhaimin Toh-Arlim: Desain Sistem Pengukuran Parameter... 


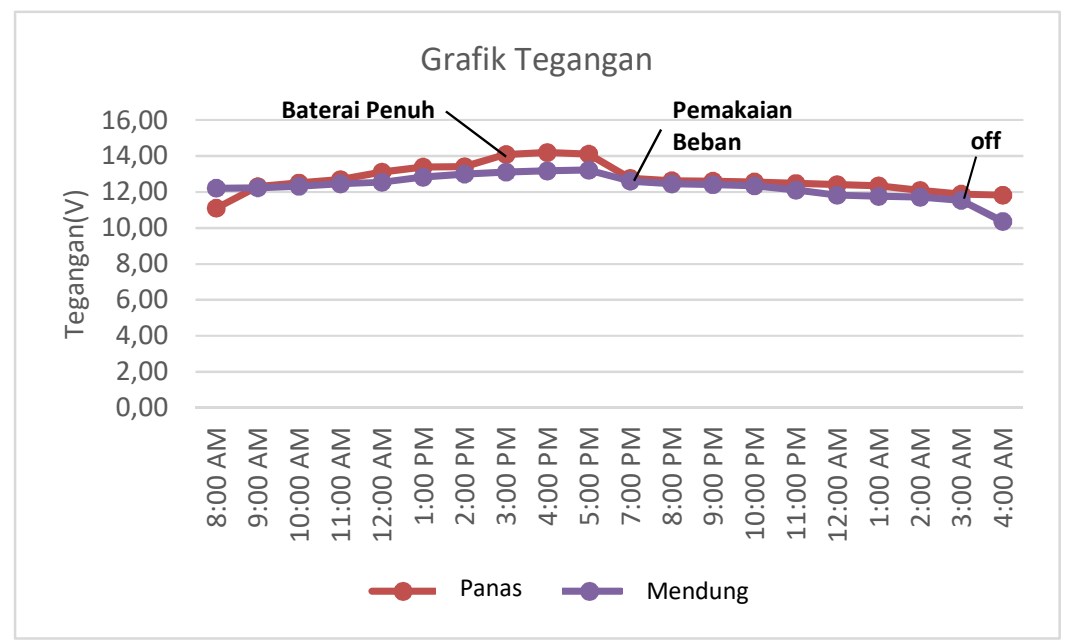

Gambar 7. Grafik voltase terhadap waktu

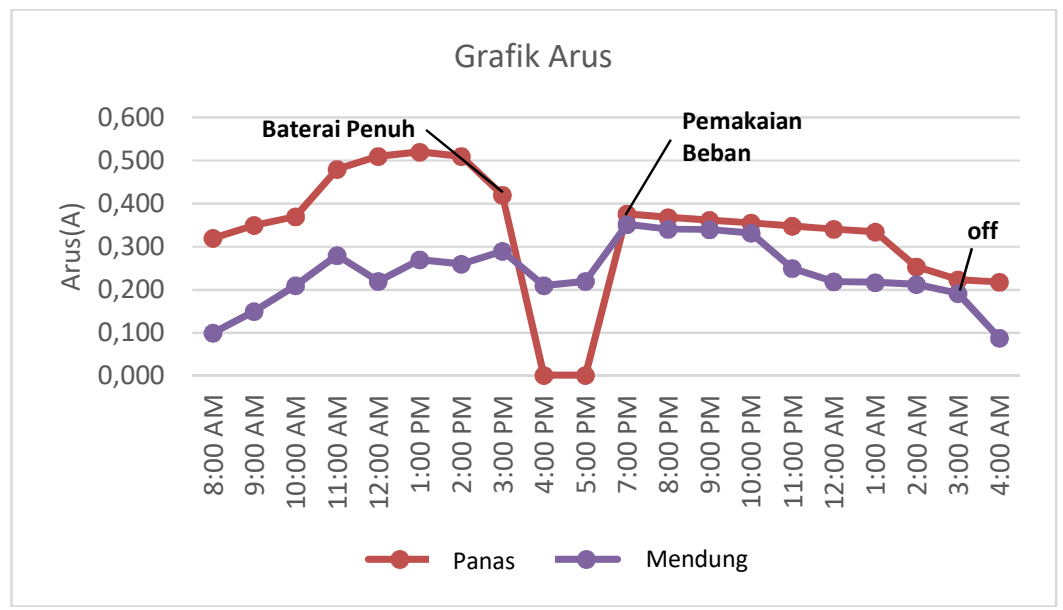

Gambar 8. Grafik arus terhadap waktu

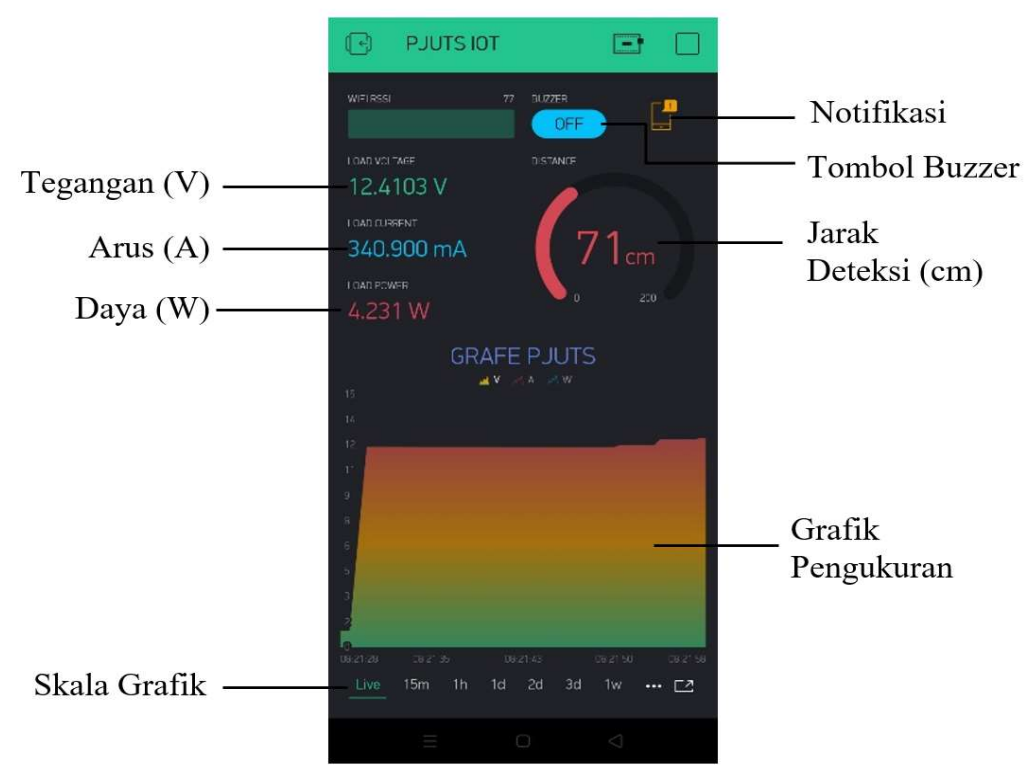

Gambar 9. Interface Aplikasi Blynk 


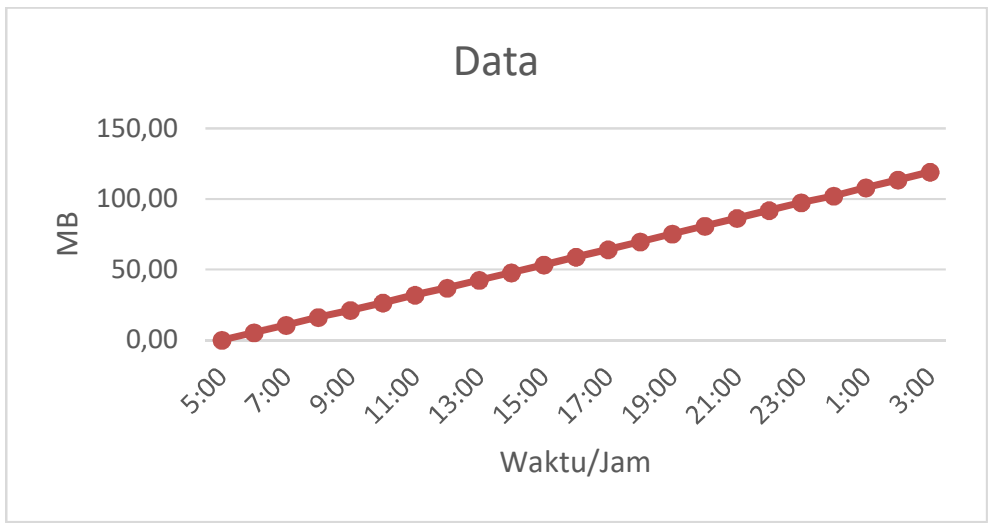

Gambar 10. Grafik data internet

\section{2) Hasil Pengujian Keamanan PJUTS}

Keamanan instrumen PJUTS dalam penelitian ini menggunakan sensor ultrasonik HCSR04 dan sensor PIR sebagai pendeteksi gerakan. Gambar 11 mengilustrasikan sistem pendeteksi gerakan perangkat. Pengoperasian sistem pendeteksi gerakan keamanan rumah saat sensor mendeteksi gerakan adalah sebagai berikut: (1) Sensor dalam keadaan siaga dan siap mendeteksi gerakan. (2) Setelah gerakan terdeteksi, sensor akan mengirimkan sinyal ke node MCU. (3) Hubungkan Node MCU ke titik akses Wifi dan sambungkan ke Internet. (4) Setelah menerima sinyal dari sensor, NodeMCU akan mengirimkan sinyal tersebut ke aplikasi Blynk yang terpasang di smartphone sebagai notifikasi saat beraktivitas. (5) Saat sensor mendeteksi gerakan, aplikasi Blynk akan menampilkan pesan "Peringatan: Perangkat mendeteksi gerakan" melalui smartphone. (6) Pengguna mengakses Blynk melalui smartphone. (7) Pengguna harus terhubung ke internet atau wifi. (8) Titik akses WiFi sebagai perantara untuk mengirim data dari node MCU ke Blynk. (9) Pengguna dapat melihat atau mengambil data dari smartphone mereka.

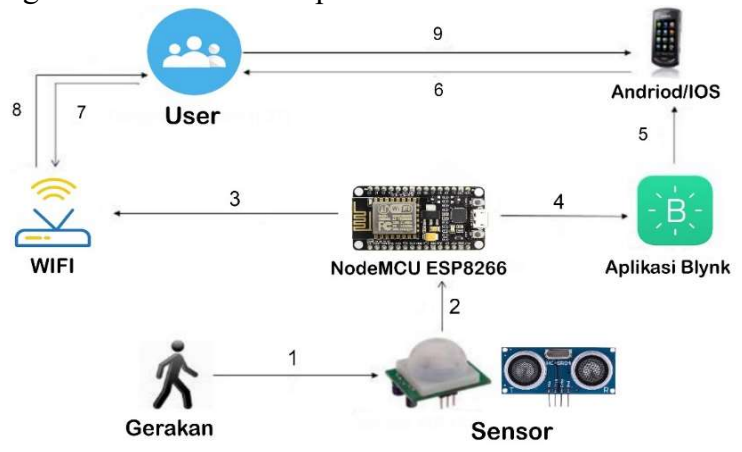

Gambar 11. Sistem pendeteksi pergerakan

Pengujian dijalankan untuk menentukan apakah perangkat keras dan perangkat lunak berfungsi dengan benar. Tes dijalankan tiga kali sampai tes lulus. Pengujian dilakukan dengan sensor PIR (Passive Infrared), aplikasi Blynk dan Thingspeak. Tabel VI adalah lembar cek notifikasi Blynk to Smartphone.

Muhaimin Toh-Arlim: Desain Sistem Pengukuran Parameter..
TABEL VI

PENGUJIAN NOTIFIKASI DARI BLYNK KE SMARTPHONE

\begin{tabular}{|c|c|l|c|c|c|}
\hline \multirow{2}{*}{ No. } & \multirow{2}{*}{$\begin{array}{c}\text { Jarak } \\
\text { obyek } \\
\text { (Meter) }\end{array}$} & & \multicolumn{3}{|c|}{ Pengujian } \\
\cline { 4 - 6 } & 1,0 & Smartphone menampilkan notifikasi & $\mathrm{B}$ & $\mathrm{B}$ & $\mathrm{B}$ \\
\hline 1 & 2,0 & Smartphone menampilkan notifikasi & $\mathrm{B}$ & $\mathrm{B}$ & $\mathrm{B}$ \\
\hline 2 & 3,0 & Smartphone menampilkan notifikasi & $\mathrm{B}$ & $\mathrm{B}$ & $\mathrm{B}$ \\
\hline 3 & 4,0 & Smartphone menampilkan notifikasi & $\mathrm{B}$ & $\mathrm{B}$ & $\mathrm{B}$ \\
\hline 4 & 5,0 & Smartphone menampilkan notifikasi & $\mathrm{B}$ & $\mathrm{B}$ & $\mathrm{B}$ \\
\hline 5 & 6,0 & $\begin{array}{l}\text { Smartphone tidak menampilkan } \\
\text { notifikasi }\end{array}$ & $\mathrm{G}$ & $\mathrm{G}$ & $\mathrm{G}$ \\
\hline 6 & & & & \\
\hline
\end{tabular}

Pada Gambar 12 Ini adalah tampilan pemberitahuan pada Blynk yang terinstal di smartphone, ketika sensor PIR mendeteksi gerakan. Pada Tabel VI, dapat dilihat hasil pengujian dari ketiga percobaan dan perbedaan jarak antara sensor dan sumber gerak yang terdeteksi. Hal ini menunjukkan bahwa sensor PIR dapat mendeteksi sumber gerakan hingga jarak 1-5 meter dan mengirimkan peringatan ke smartphone pengguna. Dapat disimpulkan bahwa semua proses yang dilakukan oleh alat, mulai dari pengujian yang dilakukan hingga mendeteksi gerakan, mengirim pemberitahuan ke Blynk hingga mengirim data, dapat berfungsi untuk perangkat tersebut. Sistem yang dihasilkan harus terhubung ke Internet agar terlihat di platform IoT. Pemrosesan data tergantung pada kekuatan sinyal hotspot atau Wi-Fi yang sedang diakses.

\section{3) Hasil Pengujian Keseluruhan Sistem PJUTS}

Sistem yang dimaksud adalah kumpulan dari semua alat yang dikelompokkan bersama. Panel surya merupakan sumber energi listrik yang mengubah energi cahaya menjadi energi listrik. Energi yang dihasilkan oleh panel surya mengalir ke enclosure controller yang meliputi solar charge controller yang mengontrol pengisian baterai dari panel surya. Ini merumahkan sistem kontrol IoT dalam bentuk NodeMCU untuk memantau energi listrik panel surya dan tegangan dan arus yang mengalir dari baterai ke lampu/beban. Selain itu, sensor INA219 sebagai sensor pembacaan tegangan dan arus dikonfigurasikan di NodeMCU dan diubah menjadi data digital dan dapat dilihat di smartphone. Dilengkapi juga dengan sistem keamanan seperti

p-ISSN:1693 - 2951; e-ISSN: 2503-2372 
sensor PIR, sensor HCSR04 dan alarm serta buzzer peringatan. Bentuk alat ditunjukkan pada Gambar 13.

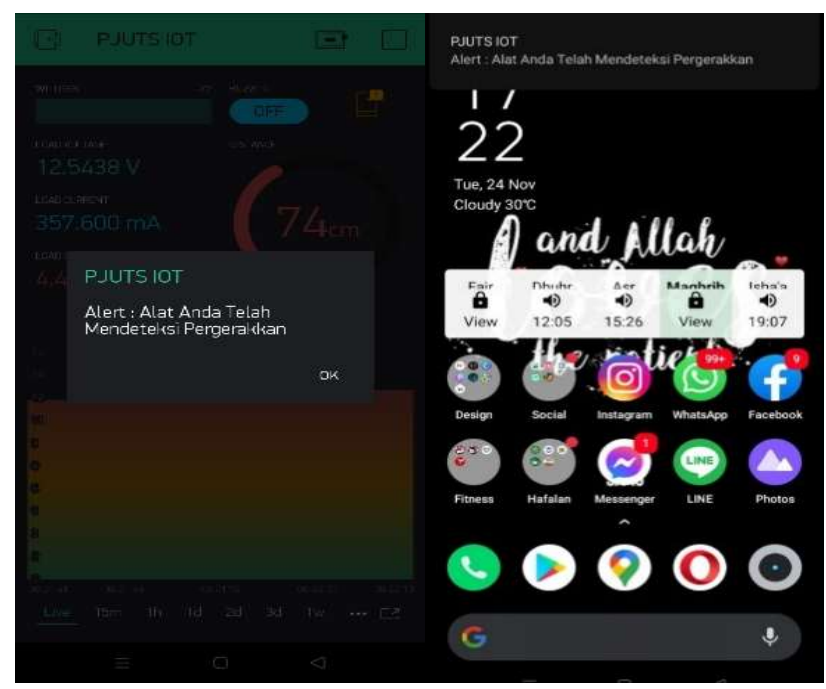

Gambar 12. Tampilan Notifikasi Blynk

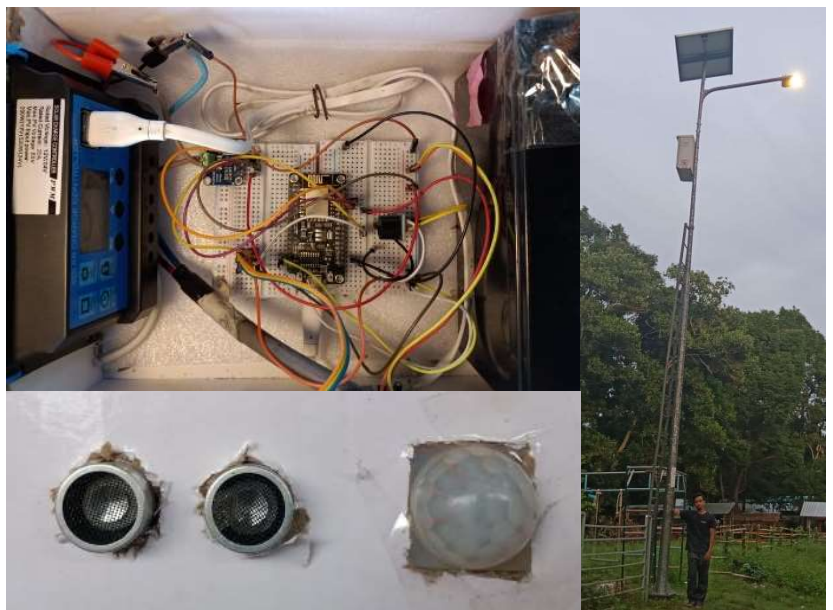

Gambar 13. Sistem pendeteksi pergerakan

\section{KESIMPULAN}

Penelitian ini membahas tentang Lampu Penerangan Jalan Umum Tenaga Surya berbasis Internet of Things (PJUIoT). Secara umum sistem dapat berjalan dengan baik yaitu dapat mengukur nilai arus, tegangan, daya dengan nilai error di bawah 1\% dan mengirimkan nilai tersebut ke aplikasi Blynk di smartphone. Pada hasil yang diperoleh dari semua pengujian, sensor INA219 dapat bekerja dengan baik, namun memiliki akurasinya yang rendah, sehingga sensor perlu diganti dengan sensor yang lebih baik. Sistem keamanan pada sistem PJUIoT dalam mendeteksi gerakan dengan jarak 1-5 meter dan mengirimkan notifikasi ke smartphone.

\section{UCAPAN TERIMA KASIH}

Kami ingin mengucapkan terima kasih kepada semua editor dan reviewer atas semua saran dan kontribusi yang telah membantu kami dalam penerbitan naskah ini. Kami juga mengucapkan terima kasih kepada pihak-pihak yang telah mendukung penelitian ini dan memberikan dukungan spiritual, moral dan material.

\section{REFERENSI}

[1] E. L. Utari, I. Mustiadi, N. Irawati, A. Qommarudin Munir, U. R. Yogyakarta, and S. Yogyakarta, "Implementasi teknologi solar panel untuk pariwisata dan pengairan di tanggulangsi kulon progo," Jurnal Pengabdian Dharma Bakti, vol. 14, no. 2, pp. 109-118, Oct. 2021.

[2] J. Sardi, A. B. Pulungan, R. Risfendra, and H. Habibullah, "Teknologi Panel Surya Sebagai Pembangkit Listrik Untuk Sistem Penerangan Pada Kapal Nelayan," Jurnal Penelitian dan Pengabdian Kepada Masyarakat UNSIQ, vol. 7, no. 1, pp. 21-26, Jan. 2020.

[3] W. Anhar et al., "Penerapan Lampu Penerangan Jalan Umum Berbasis Solar System Di RT. 50 Kelurahan Sepinggan-Balikpapan," KACANEGARA Jurnal Pengabdian pada Masyarakat, vol. 2, no. 2, pp. 67-74, May 2019.

[4] L. Mahfudz Hayusman et al., "Penerapan Teknologi Panel Surya Untuk Penerangan Jalan dan Tempat Wudhu di Musala Da'watul Khair Kota Banjarbaru," JURNAL APLIKASI DAN INOVASI IPTEKS "SOLIDITAS" (J-SOLID), vol. 4, no. 2, pp. 200-208, Sep. 2021.

[5] I. D. Arirohman et al., "Pemanfaatan Panel Surya sebagai Penerangan Jalan Umum (PJU) di Kampung Wisata Agrowidya, Rajabasa Jaya, Lampung," Jurnal Abdi Masyarakat Indonesia, vol. 1, no. 2, pp. 365372, Nov. 2021.

[6] Tri Wahyu Oktaviana Putri, "Pemanfaatan Energi Surya untuk Penerangan Jalan \& Fasilitas," Jurnal Pengabdian Pada Masyarakat Menerangi Negeri, vol. 1, no. 2, pp. 128-136, 2019.

[7] S. R. Hikmawan and E. A. Suprayitno, "Rancang Bangun Lampu Penerangan Jalan Umum (Pju) Menggunakan Solar Panel Berbasis Android (Aplikasi Di Jalan Parkiran Kampus 2 Umsida)," Elinvo (Electronics, Informatics, and Vocational Education), vol. 3, no. 1, pp. 9-17, 2018.

[8] M. J. Nahar, M. R. Sarkar, M. Uddin, M. F. Hossain, M. M. Rana, and M. R. Tanshen, "Single Axis Solar Tracker for Maximizing Power Production and Sunlight Overlapping Removal on the Sensors of Tracker," International Journal of Robotics and Control Systems, vol. 1, no. 2, pp. 186-197, 2021.

[9] P. A. K. Liando, H. Tumaliang, and L. S. Patras, "Sistem Pemantau Dan Pengendali Penerangan Jalan Umum Kota Manado Secara Terpusat Menggunakan Mikrokontroller," Jurnal Teknik Elektro dan Komputer, vol. 8, no. 2, pp. 75-82, Aug. 2019.

[10] R. P. Pratama, "Perancangan Sistem Monitoring Battery Solar Cell Pada Lampu Pju Berbasis Web," Jurnal ELTEK, vol. 12, no. 01, pp. $1693-$ 4024, 2014.

[11] D. J. Zebua, "Baterai dan Panel Surya di Kulon Progo Dicuri, Sisakan Tiang Lampu Halaman all - Kompas.com," Kompas. [Online]. Available: https://regional.kompas.com/read/2020/02/12/18595301/baterai-danpanel-surya-di-kulon-progo-dicuri-sisakan-tiang-lampu?page=all . [Accessed: 23-Apr-2021].

[12] R. Fernando, I. P. D. Wibawa, and C. Ekaputri, "Sistem Kendali Dan Monitor Penggunaan Daya Listrik Pada Perangkat Listrik Rumah Berbasis IOT," eProceeding of Engineering, vol. 15, no. 2, p. 3, 2018.

[13] I. Riadi and R. Syaefudin, "Monitoring and Control Food Temperature and Humidity using Internet of Things Based-on Microcontroller," Jurnal Ilmiah Teknik Elektro Komputer dan Informatika, vol. 7, no. 1, pp. 108-117, 2021.

[14] S. Senthil Kumar, C. Bibin, K. Akash, K. Aravindan, M. Kishore, and G. Magesh, "Solar powered water pumping systems for irrigation: A comprehensive review on developments and prospects towards a green energy approach," Materials Today: Proceedings, vol. 33, pp. 303-307, Jan. 2020.

[15] A. Fitriandi, E. Komalasari, and H. Gusmedi, "Rancang Bangun Alat Monitoring Arus dan Tegangan Berbasis Mikrokontroler dengan SMS GatewayRancang Bangun Alat Monitoring Arus dan Tegangan Berbasis Mikrokontroler dengan SMS Gateway," Electrician, vol. 10, no. 2, pp. 87-98, Jul. 2016.

[16] M. F. Wicaksono, S. Syahrul, and M. D. Rahmatya, "Development of Laboratory Equipment Inventory System Using Radio Frequency and Internet of Things," Jurnal Ilmiah Teknik Elektro Komputer dan Informatika, vol. 7, no. 2, pp. 249-258, Aug. 2021.

[17] K. Anggraini, A. Pujiastuti, and M. Zeny, "Pemanfaatan Internet of Things Pada Kendali Lampu," Compiler, vol. 6, no. 1, pp. 53-59, 2017.

[18] Y. Prasetia, A. G. Putrada, and A. Rakhmatsyah, "Evaluation of IoT- 
Based Grow Light Automation on Hydroponic Plant Growth," Jurnal Ilmiah Teknik Elektro Komputer dan Informatika, vol. 7, no. 2, pp. 314 325, Sep. 2021.

[19] F. F. Asman, E. Permata, and M. Fatkhurrokhman, "Prototype of Smart Lock Based on Internet Of Things (IOT) With ESP8266," Jurnal Ilmiah Teknik Elektro Komputer dan Informatika, vol. 5, no. 2, pp. 112-119, 2020.

[20] D. Farahiyah and B. W. Purnama, "Design Prototype of Temperature and Humidity Control and Monitoring on Weaver Ant Cage based on Internet of Things," Jurnal Ilmiah Teknik Elektro Komputer dan Informatika, vol. 7, no. 2, pp. 326-337, Sep. 2021.

[21] B. Prayitno, P. Palupiningsih, H. B. Agtriadi, S. Tinggi, and T. Pln, "Prototipe Sistem Monitoring Penggunaan Daya Listrik Peralatan Elektronik Rumah Tangga Berbasis Internet Of Things," Petir, vol. 12, no. 1, pp. 72-80, Apr. 2019.

[22] P. Sistem et al., "Pengembangan Sistem Pemantauan Konsumsi Energi Rumah Tangga Berbasis Internet of Things (IoT)," ELKOMIKA: Jurnal Teknik Energi Elektrik, Teknik Telekomunikasi, \& Teknik Elektronika, vol. 6, no. 3, p. 357, Oct. 2018.

[23] I. Gusti, P. Mastawan, E. Putra, I. Ayu, and D. Giriantari, "Monitoring Penggunaan Daya listrik Sebagai Implementasi Internet of Things Berbasis Wireless Sensor Network," Majalah Ilmiah Teknologi Elektro, vol. 16 , no. 3, pp. 50-55, Dec. 2017.

[24] A. Muhamad Alipudin, D. Notosudjono, and D. Bangun Fiddiansyah, "RANCANG BANGUN ALAT MONITORING BIAYA LISTRIK TERPAKAI BERBASIS INTERNET OF THINGS (IOT)," Jurnal Online Mahasiswa (JOM) Bidang Teknik Elektro, vol. 1, no. 1, Aug. 2018.

[25] A. D. Pangestu, F. Ardianto, and B. Alfaresi, "Sistem Monitoring Beban Listrik Berbasis Arduino Nodemcu Esp8266," Jurnal Ampere, vol. 4, no. 1, p. 187, 2019.

[26] H. I. Shahadi, M. K. Kadhim, N. M. Almeyali, and A. T. Hadi, "Design and Implementation of a Smart, Interactive, and Portable System for Monitoring of Human Vital Signs," Jurnal Ilmiah Teknik Elektro Komputer dan Informatika, vol. 7, no. 1, pp. 30-42, 2021.

[27] W. E. Sari, E. Junirianto, and G. F. Rahman, "System of Measuring PH, Humidity, and Temperature Based on Internet of Things (IoT)," Buletin Ilmiah Sarjana Teknik Elektro, vol. 3, no. 1, pp. 72-81, 2021.

[28] I. Fauzi and N. S. Widodo, "Monitoring Power Usage on Humanoid Robot Wirelessly Using the INA219 Sensor Monitoring Penggunaan Daya pada Robot Humanoid Secara Wireless Menggunakan Sensor INA219," Buletin Ilmiah Sarjana Teknik Elektro, vol. 3, no. 1, pp. 8292, 2021.

[29] I. G. A. Putra, A. A. N. Amrita, and I. M. A. Suyadnya, "Rancang Bangun Alat Monitoring Kerusakan Lampu Penerangan Jalan Umum Berbasis Mikrokontroler dengan Notifikasi SMS," Journal of Computer Science and Informatics Engineering (J-Cosine), vol. 2, no. 2, pp. 9099, Dec. 2018.

[30] M. Setiawan and R. D. Puriyanto, "Arduino-Based Battery Voltage Monitoring and SMS Gateway," Buletin Ilmiah Sarjana Teknik Elektro, vol. 2, no. 3, pp. 111-118, 2020

[31] K. P., "A Sensor based IoT Monitoring System for Electrical Devices using Blynk framework," Journal of Electronics and Informatics, vol. 2 , no. 3, pp. 182-187, Aug. 2020.

[32] I. G. H. Putrawan, P. Rahardjo, and I. G. A. P. R. Agung, "Sistem Monitoring Tingkat Kekeruhan Air dan Pemberi Pakan Otomatis pada Kolam Budidaya Ikan Koi Berbasis NodeMCU," Majalah Ilmiah Teknologi Elektro, vol. 19, no. 1, pp. 1-10, Oct. 2019.

[33] N. Nasruloh and A. R. C. Baswara, "Water Level Control and Monitoring Water Temperature in Open Evaporation Pot," Buletin Ilmiah Sarjana Teknik Elektro, vol. 3, no. 2, pp. 149-162, Oct. 2021.

[34] R. Toyib, I. Bustami, D. Abdullah, and O. Onsardi, "Penggunaan Sensor Passive Infrared Receiver (PIR) Untuk Mendeteksi Gerak Berbasis Short Message Service Gateway," Pseudocode, vol. 6, no. 2, pp. 114-124, 2019.

[35] J. Lambert, R. Monahan, and K. Casey, "Power Consumption Profiling of a Lightweight Development Board: Sensing with the INA219 and Teensy 4.0 Microcontroller," Electronics 2021, Vol. 10, Page 775, vol. 10, no. 7, p. 775, Mar. 2021.

[36] N. R. Pohan, R. Rasyid, L. Elektronika, D. Instrumentasi, and J. Fisika, "Rancang Bangun Sistem Kipas Otomatis Menggunakan Sensor PIR dan Sensor Suhu LM35," Jurnal Fisika Unand, vol. 10, no. 1, pp. 104-110,

Muhaimin Toh-Arlim: Desain Sistem Pengukuran Parameter...
Feb. 2021

[37] R. Prayogi and O. Candra, "Rancang Bangun Alat Pendeteksi Pencurian Barang Pada Truk Muatan Menggunakan Sensor PIR berbasis SMS Gateway," JTEIN: Jurnal Teknik Elektro Indonesia, vol. 2, no. 2, pp. 155-161, Jul. 2021.

[38] A. Febtriko, "Perancangan Sistem Pengamanan Ruangan Berbasis Mikrokontroler (Arduino) Dengan Metode Motion Detection," Rabit : Jurnal Teknologi dan Sistem Informasi Univrab, vol. 1, no. 1, pp. 1-7, 2016.

[39] M. A. Omran, B. J. Hamza, and W. K. Saad, "The design and fulfillment of a Smart Home (SH) material powered by the IoT using the Blynk app," Materials Today: Proceedings, Aug. 2021.

[40] E. Sutanto, T. S. Putra, A. Kuncahyojati, and E. I. Agustin, "IoT based electricity leakage current monitoring using Blynk app," AIP Conference Proceedings, vol. 2314, no. 1, p. 040004, Dec. 2020

[41] A. Ma, K. W. Mahendra, S. Ferbriyanto, A. Habibillah, and A. Nurimam, "Training on installing solar water pump for resident of singkar 1 wareng wonosari gunungkidul yogyakarta indonesia $\mid$ Jurnal Pengabdian dan Pemberdayaan Masyarakat Indonesia," Jurnal Pengabdian dan Pemberdayaan Masyarakat Indonesia, vol. 1, no. 1, pp. 31-37, 2021.

[42] S. Yuliananda, G. Sarya, and R. Retno Hastijanti, "Pengaruh Perubahan Intensitas Matahari Terhadap Daya Keluaran Panel Surya," Jurnal Pengabdian LPPM Untag Surabaya Nopember, vol. 01, no. 02, pp. 193202, 2015.
p-ISSN:1693 - 2951; e-ISSN: 2503-2372 
\{Halaman ini sengaja dikosongkan\} 